2013-08-28

\title{
Influence of sediment redox conditions on uranium mobilisation during saline intrusion
}

\section{Eagling, J}

http://hdl.handle.net/10026.1/3059

10.1016/j.chemgeo.2013.08.030

CHEMICAL GEOLOGY

Elsevier BV

All content in PEARL is protected by copyright law. Author manuscripts are made available in accordance with publisher policies. Please cite only the published version using the details provided on the item record or document. In the absence of an open licence (e.g. Creative Commons), permissions for further reuse of content should be sought from the publisher or author. 
Influence of sediment redox conditions on uranium mobilisation during saline intrusion

Jane Eagling, ${ }^{1,2} *$ Paul J. Worsfold, ${ }^{1}$ William H. Blake, ${ }^{2}$ and Miranda J. Keith-Roach ${ }^{1.2 .3}$

${ }^{1}$ Biogeochemistry and Environmental Analytical Chemistry Group, Biogeochemistry Research Centre, Plymouth University, Plymouth, PL4 8AA, UK

${ }^{2}$ Consolidated Radio-isotope Facility, Plymouth University, Plymouth PL4 8AA, UK ${ }^{3}$ Kemakta Konsult, Box12655, 11293 Stockholm, Sweden.

*Corresponding author: E-mail: jane.eagling@plymouth.ac.uk

Telephone $+44(0) 1752584568$

NOTICE: this is the author's version of a work that was accepted for publication in Chemical Geology. Changes resulting from the publishing process, such as peer review, editing, corrections, structural formatting, and other quality control mechanisms may not be reflected in this document. Changes may have been made to this work since it was submitted for publication. A definitive version was subsequently published in Chemical Geology, [VOL 357, (DATE 24 October 2013)] DOI 10.1016/j.chemgeo.2013.08.030

\section{Abstract (word count 212)}

In the UK, several coastal nuclear sites have been identified as vulnerable to future sea level rise. Legacy contamination at these sites has accumulated in sub-surface sediments at risk of future seawater inundation and intrusion. Porewater salinization, changes in $\mathrm{pH}$ and the influx of oxygen into sediments may impact the stability of sediment associated uranium (U). In this study, saturated column experiments were performed to compare the mobilisation of $U$ from oxic and reduced sediments into seawater under environmentally relevant flow conditions. Uranium release profiles were independent of the initial geochemistry of the sediments. Uranium release from the sediments was kinetically controlled, showing relatively slow 
desorption kinetics, with release initially limited by the impact of the sediments on the $\mathrm{pH}$ of the seawater. Significant U release only occurred when the $\mathrm{pH}$ was sufficiently high for the formation of U-carbonate complexes $\left(\mathrm{pH}_{\text {oxic }} 6.3\right.$; $\left.\mathrm{pH}_{\text {reduced }} 7.5\right)$. Uranium was more strongly bound to the reduced sediments and after 400 pore volumes of seawater flow, release was more extensive from the initially oxic (46\%) compared with initially nitrate reducing (27\%) and iron reducing (18\%) sediments. The products of iron cycling appeared to act as a buffer limiting $U$ mobilisation, but the on-going dissolution of the Fe-phases suggests that they did not form a permanent protective layer.

\section{Highlights}

- Seawater intrusion promotes U mobilisation from oxic and reduced sediments

Keywords: Uranium; porewater salinization; desorption; transport; oxic and reduced sediments; oxidation

\section{Introduction}

Radioactive waste is generated throughout the nuclear cycle and accidental discharges, and 70 years of nuclear activities have resulted in a significant legacy of contaminated soil and sediment at nuclear facilities worldwide (McKenzie and Armstrong-Pope, 2010; Reistad et al., 2008; Zachara et al., 2013). Due to their need for cooling water several nuclear facilities

46 (example.g. in the UK, USA and Japan) are located in low lying coastal areas and this close 
47 proximity to the shoreline raises questions regarding their future safety with respect to projected climate change and rising sea levels.

Much of the contamination at nuclear sites has accumulated in the sub-surface sediments

50

(McKenzie and Armstrong-Pope, 2010; McKinley et al., 2006) and these will be at risk of seawater inundation and intrusion. Uranium is a long lived radionuclide $\left({ }^{238} \mathrm{U} \mathrm{t}_{1 / 2}=4.5 \times 10^{9}\right.$ years) and is both a persistent and widespread contaminant found at uranium mining and mill tailings sites, nuclear facilities and waste disposal sites worldwide (McKinley et al., 2006; Riley and Zachara, 1992). All of the U isotopes are alpha emitters, chemotoxic and radiotoxic and any remobilisation of $U$ from sediments may lead to human dietary exposure through the consumption of contaminated food (Belles et al., 2013).

Localised areas of reduced sediments are found in sub-surface environments at legacy nuclear sites. The redox conditions in sub-surface sediments are variable; therefore uranium is found in both the reduced U(IV) and oxidised U(VI) forms (Sharp et al., 2011; Zhou and Gu, 2005). Uranium(VI) sorbs to a variety of minerals and related phases including clays (Rodriguez et al., 2008; Whicker et al., 2007), iron (oxy)hydroxides (Duquene et al., 2008; Gómez et al., 2006; Martinez et al., 1995; Sherman et al., 2008) and aluminium and silica oxides (Sylwester et al., 2000). Uranium(VI) can also co-precipitate with iron oxy-hydroxides and calcium carbonates (Duff et al., 2002; Reeder et al., 2000) and so its behaviour, at least in some situations, can be influenced by the cycling of other elements in the system. Uranium(IV) species form under reducing conditions, and have a higher affinity for surface binding sites and a lower solubility than U(VI) species (Langmuir, 1978). The product of $\mathrm{U}(\mathrm{VI})$ reduction is often uraninite $\left(\mathrm{UO}_{2}\right)$ (Campbell et al., 2011; Ginder-Vogel et al., 2006). Additionally, U(VI) that is sorbed to sediments surfaces can be reduced to sorbed U(IV) phases (Begg et al., 2011; Gu et al., 2005). 
71 Uranium(VI) mobilisation can be promoted by the formation of U(VI) carbonate complexes,

72 such as $\mathrm{UO}_{2}\left(\mathrm{CO}_{3}\right)_{2}{ }^{2-}$ or $\mathrm{UO}_{2}\left(\mathrm{CO}_{3}\right)_{3}{ }^{4-}$, when the $\mathrm{pH}$ is $>6$ (Choy et al., 2006; Zhou and Gu,

73 2005). Thermodynamic data suggests that carbonate does not complex $\mathrm{U}(\mathrm{IV})$ or promote $\mathrm{UO}_{2}$

74 dissolution under reducing conditions (Guillaumont et al., 2003). However, the production of

$75 \mathrm{CO}_{3}{ }^{2-}$ and $\mathrm{HCO}_{3}{ }^{-}$during microbial respiration has been shown to promote the formation of

76 stable uranyl carbonate complexes under reducing conditions (Wan et al., 2008).

77 Since sediments can interact with seawater and lower its $\mathrm{pH}$ until the sediment's reactive

78 phases are exhausted, column experiments have been shown to be more appropriate than

79 batch experiments for investigating the impact of seawater inundation on U mobilisation from

80 oxic Dounreay sediments (Eagling et al., 2013). In these column experiments, pH changes

81 were monitored as a function of flow volume and $\mathrm{U}$ mobilisation, which began when the $\mathrm{pH}$

82 reached 6.9 due to the formation of U-carbonate complexes. As the $\mathrm{pH}$ increased further,

83 mobilisation of $\mathrm{U}$ was slow and the elution profile was consistent with kinetically slow

84 release processes.

85 As well as inducing pore water salinization and altering the porewater $\mathrm{pH}$, seawater intrusion

86 introduces oxygen into reduced sediments, allowing the re-oxidation of sediment associated

$87 \mathrm{U}(\mathrm{IV})$. Uranium re-oxidation has been observed in batch experiments at circumneutral $\mathrm{pH}$ where U(IV) was rapidly oxidised to U(VI), followed by mobilisation (Law et al., 2011), and this can be accelerated by bicarbonate complexation (Ulrich et al., 2008). However, sediment

90 re-oxidation may not always lead to the mobilisation of U(VI); e.g. Zhong et al., (2005)

91 found that during re-oxidation U mobilisation from Fe-rich Oak Ridge sediments was limited

92 by sorption of U(VI) to the secondary Fe(III) minerals formed. Additionally, Fe(II) sorbed to

93 the outer surface of sediments may re-oxidise to form an Fe(III) oxide veneer that acts as a

94 diffusional barrier, protecting against U(IV) re-oxidation (Zhong et al., 2005). 
Relatively few studies have investigated the mobilisation of U(VI)/(IV) from sediments under more environmentally relevant flow conditions (Abdelouas et al., 1999; Komlos et al., 2008a; Komlos et al., 2008b; Moon et al., 2007; Moon et al., 2009). Re-oxidation studies have shown that secondary products formed during Fe reduction did not protect U(IV) from oxidation and mobilisation under flow conditions (Komlos et al., 2008b; Moon et al., 2007). A similar effect resulting from the low solubility of Fe re-oxidation products has been observed during Tc remobilisation from Fe rich sediments, with flow conditions promoting more Tc mobilisation compared with batch systems (Eagling et al. 2012). However, iron sulphide precipitates formed under more extensively reducing conditions have been reported to act as a buffer, preventing $\mathrm{U}$ oxidation and/or release under flow conditions (Abdelouas et al., 1999; Moon et al., 2009). Mackinawite was particularly effective and provided long term protection when formed in sufficient quantities (Abdelouas et al., 1999). Uranium oxidation and/or release from geochemically reducing sediments into seawater has not, however, been investigated.

The aim of this study was to investigate how the initial geochemical conditions of an Fe-rich sediment affect the mobilisation of $U$ during seawater intrusion. Iron-rich sediments with similar properties to the Sellafield, UK site were contaminated with U and either stored open for six months in the dark, or sealed and stored in the dark for different lengths of time to allow the natural microbial communities to change the geochemical redox conditions to nitrate-reducing and then iron-reducing. The sediments were then used in column experiments simulating seawater intrusion to investigate $U$ cycling and release processes in sub-surface environments under environmentally relevant flow through conditions.

\section{METHODS}


2.1. Sediment and water. Sandy, iron rich sediments with a similar mineralogical composition (quartz, silicates and feldspars) and geochemical characteristics to the Quaternary alluvial flood plain deposits that underlie the Sellafield site (Cumbria, UK), as previously characterised by Law et al. (2010), were sampled from Crediton UK (Lat: $50^{0} .8091^{\prime} \mathrm{N}$; Long: $\left.03^{0} .6815^{\prime} \mathrm{W}\right)$, homogenised and sieved $(<2 \mathrm{~mm})$ in a field-moist state. Seawater was collected from the L4 coastal monitoring station in the Western English Channel to avoid estuarine influence (see www.westernchannelobservatory.org.uk ) and filtered (0.4 $\mu \mathrm{m}$ Nuclepore ${ }^{\mathrm{TM}}$ track edge membrane, Whatman). Characterisation of the sediments is detailed elsewhere (Eagling et al., 2012). A synthetic groundwater solution (pH

$127=7.2$ ) representative of the Sellafield region (Wilkins et al., 2007) was prepared by dissolving salts in Milli-Q water (the constituents are shown in SI Table 1).

2.2. Contamination of oxic sediments with $\mathbf{U}$. Sieved sediment $(<2 \mathrm{~mm})$ was amended with simulated groundwater containing $\mathrm{U} \approx 25 \mu \mathrm{M}\left(\mathrm{UO}_{2}\left(\mathrm{NO}_{3}\right)_{2} \cdot 6 \mathrm{H}_{2} \mathrm{O}\right)$ at a $1(\mathrm{~g}): 1(\mathrm{~mL})$ sediment to solution ratio. After a 7 day sorption period, the supernatant was separated from the sediment by centrifugation (10 min at $7500 \mathrm{~g}$ ). Moist sediments were transferred to a container and stored in the dark at $21{ }^{\circ} \mathrm{C}$ for a 6 month ageing period. Periodically the container was opened to allow entry of air and ensure that the sediments did not become reducing.

2.3. Contamination of anoxic sediments with $\mathbf{U}$. The $U$-amended synthetic groundwater was added to sieved sediment to give a $1(\mathrm{~g}): 1(\mathrm{~mL})$ sediment:solution ratio and incubated anaerobically in $250 \mathrm{~mL}$ serum bottles in the dark at $21^{\circ} \mathrm{C}$. The natural microbial consortium reduced the sediments over time without the addition of amendments. At pre-selected time intervals the serum bottles were transferred to an anaerobic chamber (COY Laboratory

141 Products Inc., $\mathrm{MI} ; 95 \% \mathrm{~N}_{2}, 5 \% \mathrm{H}_{2}, \mathrm{O}_{2}<50 \mathrm{ppm}$ ) and the slurries transferred into centrifuge 142 vessels. The Eh and $\mathrm{pH}$ of the slurries were measured using hand held electrodes. Sediments 
were separated from the porewater by centrifugation and then the $U$ concentration in the supernatant was determined by ICP-MS (Thermo X Series 2, Thermo Scientific). Redox

145 indicators $\left(\mathrm{NO}_{3}{ }^{-}\right.$and $\mathrm{SO}_{4}{ }^{2-}$ ) were determined by ion chromatography (Dionex DX-500). Acid (0.5 M HCl) extractable Fe(II) was determined spectrophotometrically $\left(\lambda_{\max }=562 \mathrm{~nm}\right)$ using

147 ferrozine (Lovely and Phillips, 1986; Stookey, 1970). The incubations were targeted to obtain nitrate-reducing and iron-reducing conditions.

2.4. Column experiments. Column experiments were used to simulate the intrusion of seawater into the sediment in order to investigate the release of $U$ from contaminated sediments. Each contaminated sediment (i.e. oxic, nitrate reducing and iron reducing) was packed into a separate polyetheretherketone (PEEK) self-pack column (50 mm x 10 mm; Applied Biosciences) according to Eagling et al. (2012). In order to avoid re-oxidation, reduced sediments were packed into the columns within the anaerobic chamber. The columns were then removed from the anaerobic chamber and oxic seawater was pumped through at a constant flow rate of $1.2 \mathrm{~mL} \mathrm{~h}^{-1}$ using an HPLC pump. The eluate was collected in fractions using a fraction collector at 1.2-3.6 mL intervals. Pre-weighed vessels were placed after every 10 sample vials to check the flow rate (uncertainties associated with the flow rate were $<5 \%$ ).

Experiments involving oxic sediment were shorter (400 pore volumes) than those with initially nitrate-reducing and iron-reducing sediments (1000 pore volumes). Flow was stopped for 2 weeks after approximately 765 pore volumes to investigate whether the $U$ in the eluate was in equilibrium with sorbed uranium in the nitrate- and iron-reducing sediment columns (Qafoku et al., 2005; Yin et al., 2011). At the end of each experiment, the column porosity was characterised using a conservative $\mathrm{Br}^{-}$tracer injected as a pulse onto the column. At the end of each experiment, the column porosity was characterised using a conservative $\mathrm{Br}^{-}$tracer injected as a pulse onto the column. There was only minor variation in $\mathrm{Br}^{-}$

167 breakthrough (SI Figure S1), which indicates that there was only minor variability in column 
168 packing and hence in the column porosity. The linear column flow velocities were $268 \mathrm{~m} \mathrm{y}^{-1}$ 169 (oxic aged), $235 \mathrm{~m} \mathrm{y}^{-1}$ (nitrate-reducing) and $262 \mathrm{~m} \mathrm{y}^{-1}$ (iron-reducing). These flow velocities

170 are within the range of flow velocities observed in sandy aquifers under natural

171 hydrogeological conditions (Mackay et al., 1985). The $\mathrm{pH}$ and Eh of the eluate were

172 measured as soon as practically possible after elution and the concentrations of $\mathrm{U}, \mathrm{Fe}$ and $\mathrm{Br}$

173 were determined by ICP-MS with collision cell technology to eliminate ${ }^{40} \mathrm{Ar}^{16} \mathrm{O}$ interference

174 on the ${ }^{56} \mathrm{Fe}$ signal. Standards were matrix matched (10 \% seawater) and ${ }^{115} \mathrm{In}$ and ${ }^{209} \mathrm{Bi}$ were

175 used as internal standards to account for instrumental drift. Independent standard checks were

176 used to ensure both quality control and consistency between runs. All results were blank

177 corrected to account for $\mathrm{U}$ and Fe naturally present in seawater. The limits of detection for Fe 178 and $\mathrm{U}$ were $3.0 \mathrm{nM}$ and $0.09 \mathrm{nM}$ respectively.

179 3. RESULTS AND DISCUSSION

180 3.1. Sediment characterisation. Sediment from the same location has been described

181 previously (Eagling et al. 2012) and characterisation data are shown in SI Tables 2 and 3. The 182 sediment mineralogy was dominated by quartz but also contained silicates, feldspars and 183 hematite, with a high proportion of sand (61 \%) and silt (36 \%) and a low clay content (3\%).

184 The sediments were iron rich $\left(420 \pm 6 \mathrm{mmol} \mathrm{Fe} \mathrm{kg}^{-1}\right)$, had a surface area of $6.57 \mathrm{~m}^{-2} \mathrm{~g}^{-1}$, a 185 cation exchange capacity of the $9.3 \pm 1 \mathrm{cmol} \mathrm{kg}^{-1}$ and a pH of $3.9 \pm 0.3$ (measured in Milli-Q 186 water using a 1:1 sediment: solution ratio). The total organic carbon content of the sediment 187 was $2 \% \mathrm{w} / \mathrm{w}$.

188 3.2. $\mathrm{U}$ immobilisation under oxic conditions. Uranium sorbed rapidly to the oxic sediments, 189 with $96 \pm 2 \%$ of the uranium sorbed after the 7 day period. There was no significant change 190 in the percentage of $\mathrm{U}$ sorbed during the subsequent 6 month ageing period and, because 
conditions remained oxic throughout this time, $\mathrm{U}$ was expected to be associated with the sediments as $\mathrm{U}(\mathrm{VI})$.

3.3. $\mathbf{U}$ immobilisation during reduction. The conditions in the sealed serum bottles became increasingly reducing over time (Table 1). After 30 days, pore water nitrate concentrations had decreased significantly, indicating that nitrate reduction had been the dominant respiration process. The $\mathrm{pH}$ of the sediment had increased, which is consistent with the generation of $\mathrm{CO}_{3}{ }^{2-}$ during nitrate reduction (Law et al., 2010). In these sediments, $99 \pm 0.5 \%$ of U(VI) had been removed from solution. In general U(VI) reduction does not occur alongside nitrate reduction (Finneran et al., 2002), and it is likely that $U$ remained in the oxidised form, i.e. as $\mathrm{U}(\mathrm{VI})$.

After a 120 day reduction period, the nitrate concentration was below the limit of detection. Iron reduction had started by this time, as indicated by ingrowth of $0.5 \mathrm{M} \mathrm{HCl}$ extractable Fe(II) $\left(16 \pm 1 \mathrm{mmol} \mathrm{kg}^{-1}\right)$. Porewater $\mathrm{SO}_{4}{ }^{2-}$ concentrations increased over the 120 day reduction period, evidence that sulfate reduction had not occurred in the sediments. In these sediments $98 \pm 1 \%$ of the $U$ had become associated with the sediments. Abiotic or microbial reduction of $\mathrm{U}(\mathrm{VI})$ to $\mathrm{U}(\mathrm{IV})$ is generally observed in sediments alongside Fe(III) reduction (Begg et al., 2011; Finneran et al., 2002; Gu et al., 2005; Senko et al., 2002). However, in our experiments, there was no significant change in the percentage of $U$ sorbed to the sediments as conditions changed from nitrate- to iron-reducing, which suggests that the oxidation state of U did not change. Calculations performed with the Hydra hydrochemical database with MEDUSA software (Puigdomenech, 2004) also predicted that U(VI) species would dominate. Therefore it is likely that $\mathrm{U}$ remained as $\mathrm{U}(\mathrm{VI})$ throughout the experiments. Begg et al. (2011) used sequential extractions to show that U(IV) sorbed to reduced iron rich

214 sediments was bound more strongly than U(VI) sorbed to oxic sediments. Sequential extraction data from our experiments however showed no significant change in the 
fractionation of $U$ in the three sediments (SI Figure 2), providing further evidence that there was no change in the oxidation state of $U$ in the systems reported here.

\subsection{Changing geochemical conditions within the column during seawater intrusion.}

The $\mathrm{pH}$ of the eluent from all three columns was initially low (3.4-5.9), and increased

with flow volume, reaching the $\mathrm{pH}$ of the inflowing seawater (7.8) after 33-160 pore volumes.

The nitrate-reducing and iron-reducing sediments showed a similar $\mathrm{pH}$ elution profile, but

with a slower increase in the oxic sediment column due to the lower initial $\mathrm{pH}$ (Table 1). The $\mathrm{pH}$ of the outflow was comparable with that of the other two columns after $\approx 160$ pore

volumes of seawater had been eluted. The $\mathrm{pH}$ then remained relatively constant $(7.2$ - 8.0)

over the remainder of each experiment. A similar rapid reduction in $\mathrm{pH}$ has been observed previously in column experiments (Eagling et al., 2012). The low initial $\mathrm{pH}$ of the eluents in all cases is probably due to the high ionic strength of seawater displacing protons sorbed to the sediments, hence decreasing the pH (Wong et al., 2010), coupled with the high sediment to solution ratios at the start of the column experiments. The 2 week stop-start event applied to the initially nitrate-reducing and iron-reducing columns had no effect on the $\mathrm{pH}$.

The Eh of the outflow from the oxic columns remained relatively constant (370 - 440

$\mathrm{mV})$. In contrast, the Eh of the nitrate-reducing and iron-reducing columns increased rapidly, suggesting that the sediments were re-oxidised as seawater flowed through the column. It is interesting to note that despite re-oxidation, the Eh remained lower in the oxic column throughout the experiment and the redox conditions in the initially oxic and initially anoxic columns were not the same at any point. The initially Fe-reducing sediments re-oxidised more quickly than the nitrate-reducing sediments, and the Eh remained relatively constant throughout the experiment. The stop-start event had no effect on the Eh of the initially iron 
reducing sediments. In contrast, the Eh of the nitrate-reducing column was variable, which may be due to flow path modifications and channeling resulting from oxidative mineral dissolution and precipitation (Eagling et al., 2012; Moon et al., 2009). The Eh decreased in the initially nitrate-reducing sediments when the flow was stopped but the reason for this is unclear.

In the first 10 pore volumes eluted from the column there was a pulse of Fe (3.3 $\mu \mathrm{M})$ mobilised from the oxic column, suggesting that a limited pool of labile or exchangeable Fe was readily desorbed (Figure 1). Release of Fe from the initially iron-reducing sediments was also immediate and significant $(188 \mu \mathrm{M})$ and was due to $\mathrm{Fe}(\mathrm{II})$ in the pore waters. After the initial release, Fe leached steadily from the oxic and iron-reducing sediments over the course of the experiment. In contrast, the onset of flow did not result in the initial mobilisation of Fe from the nitrate-reducing sediments. In these columns Fe release was variable and increased between 20 and 120 pore volumes but did not correlate with changes in Eh or $\mathrm{pH}$, supporting the flow path modification hypothesis. After the 2 week stop-start flow event Fe was mobilised from both the nitrate-reducing and iron-reducing sediments within the first pore volume when flow was resumed. The concentration of Fe released rapidly decreased to prestop/start flow concentrations, suggesting that this pool of labile Fe was limited.

\subsection{Uranium cycling during inundation and intrusion}

In the first 10 pore volumes, there was a pulse release of $U$ from the oxic sediments which was not seen from the initially reduced sediments (both nitrate-reducing and ironreducing). This suggests that a limited ( $0.3 \%)$ but rapidly exchangeable fraction of U(VI) was sorbed to the surface of the oxic sediments. The U pulse was concurrent with the low $\mathrm{pH}$ and Fe pulse release observed. After this, in the early period ( $<40$ pore volumes) in every 
column profile, no measurable $\mathrm{U}$ was mobilised from the sediments. The eluent $\mathrm{pH}$ was also low throughout this period $(<6.3)$, suggesting that the increased ionic strength of the pore

266 waters alone had a limited effect on U mobilisation. Uranium release was only observed after the $\mathrm{pH}$ of the eluted seawater increased above 6.3. This is consistent with the desorption of surface associated U(VI) promoted by the formation of soluble U(VI) species such as $\mathrm{UO}_{2}\left(\mathrm{CO}_{3}\right)_{2}{ }^{2-}$ and $\mathrm{UO}_{2}(\mathrm{CO} 3)_{3}{ }^{4-}$ (Dong et al., 2005; Duff et al., 2002; Fox et al., 2006; Zhong et al., 2005). Uranyl carbonate complexes are less likely to be sorbed to sediment surfaces and therefore will increase U mobility in sub-surface environments (Wazne et al., 2003). Uranium was mobilised after fewer pore volumes of seawater had flowed through the initially nitrate-reducing (38 pore volumes) and iron-reducing (22 pore volumes) sediments compared with the oxic sediments (46 pore volumes). However, $\mathrm{U}$ was released at a lower $\mathrm{pH}$ from the oxic sediments ( $\mathrm{pH}$ 6.3) compared with the initially reduced sediments ( $\mathrm{pH} \sim 7.5)$.

After the onset of mobilisation, $U$ release was most rapid from the oxic sediments and maximum concentrations of $U$ were eluted after fewer pore volumes of seawater had flowed through the column (85 pore volumes) compared with the initially anoxic sediments (nitratereducing 140 pore volumes; iron-reducing 150 pore volumes). Additionally, higher concentrations of $U$ were mobilised from the oxic sediments $\left(U_{\max } 220 \mathrm{nM}\right)$ compared with the anoxic sediments (nitrate-reducing $115 \mathrm{nM}$; iron-reducing $72 \mathrm{nM}$ ). These observations, together with the higher $\mathrm{pH}$ associated with the onset of $\mathrm{U}$ mobilisation from the anoxic sediments suggest that the $U$ was more strongly bound to the anoxic sediments. This is consistent with the physico-chemical changes that take place in the sediments during reduction and/or during re-oxidation in seawater. Despite the differences in the maximum concentration released, a similar fraction of the $U(\approx 6 \%)$ initially associated with the sediments was released between time zero and the time at which maximum concentrations of U were observed. This shows that although $U$ was mobilised at different rates and was 
associated with different binding sites in the three sediments, a similar fraction of $U$ was readily mobilised from each sediment during this period.

After the peak U release (85-150 pore volumes), there was a slower on-going release, producing a tail in all of the elution profiles (Figure 1a). This tailing is indicative of kinetically controlled release, which involves U release from a range of binding sites with different desorption kinetics and/or a re-distribution between slow and fast reactive sites (Handley-Sidhu et al., 2009; Liu et al., 2008; Qafoku et al., 2005). The differences in the shape of the release profiles during the tailing section (Figure 2) suggests that more than one release process was occurring. The majority of the U mobilised (83-90 \%) was released during the tail section (i.e. after the peak in U concentration was observed). Therefore relatively slow desorption kinetics dominated the mobilisation of $U$ from all of the sediments.

Flow was stopped for 2 weeks in the initially nitrate-reducing and iron-reducing columns. During this period U was mobilised from the nitrate- reducing and iron-reducing sediments (Figure 1a), which provides further evidence that U release was kinetically controlled. The highest concentrations of $U$ were mobilised in the first pore volume after flow resumed; $U$ concentrations then decreased rapidly and only a small fraction of the $U$ 305 originally associated with the sediments was released from the nitrate-reducing (1.4\%) and iron-reducing (0.9\%) sediments respectively. Uranium mobilisation correlated with Fe release in the first 10 pore volumes when flow was resumed ( $r=0.875$ (nitrate-reducing), 0.970 (iron-reducing); $\mathrm{p}=0.000, \mathrm{n}=12$ ); evidence that Fe phases play a role in controlling $\mathrm{U}$ mobility, with desorption/dissolution of Fe phases promoting U release. The association and cycling of $\mathrm{U}$ with $\mathrm{Fe}$ (oxy)hydroxides has also been observed in marine sediments (Barnes and Cochran, 1993; Morford et al., 2007). 

been released from the oxic sediments ( $46 \%$ of the total $U$ initially associated with the sediments) compared with the nitrate-reducing sediments (27\%) and iron-reducing sediments (18\%). Release from the reduced sediments occurred throughout the experiment and in total $53 \%$ was released from nitrate-reducing sediments and 38 \% from initially iron-reducing sediments $(\approx 1000$ pore volumes). The lower $U$ release from the iron-reducing sediment is consistent with the hypothesis that low solubility Fe(III) phases form during the re-oxidation of Fe(II) and these phases provide effective surfaces for U sorption and/or a physical barrier preventing U mobilisation. The stop-start events showed that kinetically slow Fe mobilisation correlated with U mobilisation, supporting this hypothesis. Although slow, the release of both $\mathrm{U}$ and Fe continued throughout the experiment, which suggests that $U$ mobilisation was only retarded, rather than prevented by these phases. Similar results have been reported in freshwater sediments (Moon et al., 2009; Zhong et al., 2005) where Fe(II) containing minerals did not permanently protect $U$ from mobilisation.

The results from the oxic sediment columns show similarities with those obtained in a similar experiment conducted using sediment from the nuclear site at Dounreay (Scotland) (Eagling et al., 2013). These two sediments have several common characteristics; they are both iron rich, acidic, sandy loams with a low clay content and similar cation exchange capacities (SI Tables S2 and S3). Uranium was mobilised at a similar $\mathrm{pH}$ from the two sediments (this study $\mathrm{pH}$ 6.3; Dounreay $\mathrm{pH}$ 6.9), and both peak profiles showed long tailing sections (Figure 2). There were differences in the elution volume before $\mathrm{U}$ began to be released (85 pore volumes in this study compared with 160 pore volumes for Dounreay sediment), however a similar fraction $(\approx 47 \%)$ of sorbed $U$ was mobilised from each sediment over 400 pore volumes, with the majority of the $\mathrm{U}$ mobilised during the tail section. The fact that these two sediments show similar $U$ remobilisation behavior supports the view 
that these trends can be extrapolated to predict the impact of future sea level rise on other legacy nuclear sites with similar geochemical conditions.

\subsection{Conclusions and Environmental Implications}

341 Seawater intrusion into U-contaminated sediments causes U mobilisation by introducing 342 oxygen into reduced sediments and increasing the $\mathrm{pH}$ of the sediment pore waters. However,

343 U release from the sediment was kinetically controlled, showing relatively slow desorption

344 kinetics. The profiles differed according to the initial geochemical conditions and there was

345 evidence that Fe-phases play an important role in retarding U release. However, the on-going

346 dissolution of the Fe-phases suggests that they do not form a permanent protective layer.

347 Despite the differences in the initial geochemistry of the sediments prior to pore water

348 salinization and quantitative differences in $U$ release, the general trends in the $U$ release

349 profiles were broadly similar. The oxic column data showed excellent agreement with results

350 from similar column experiments using Dounreay sediments. This suggests that, regardless of

351 the geochemical redox conditions, U(VI) release is; (a) dependent on pH, (b) kinetically slow, 352 and (c) on-going from iron rich, sandy loam sediments with a low clay content.

\section{Acknowledgments}

355 This research was funded by the Natural Environment Research Council (grant

356 NE/C506799/1: Studentship NE/H527116/1). We would like to thank Dr Andrew Fisher for

357 technical advice and Prof. Geoff Millward for constructive comments.

\section{Appendix A. Supplementary data}


359 Supplementary data to this article can be found online at

360 http://dx.doi.org/10.1016/j.chemgeo.2013.08.030. 

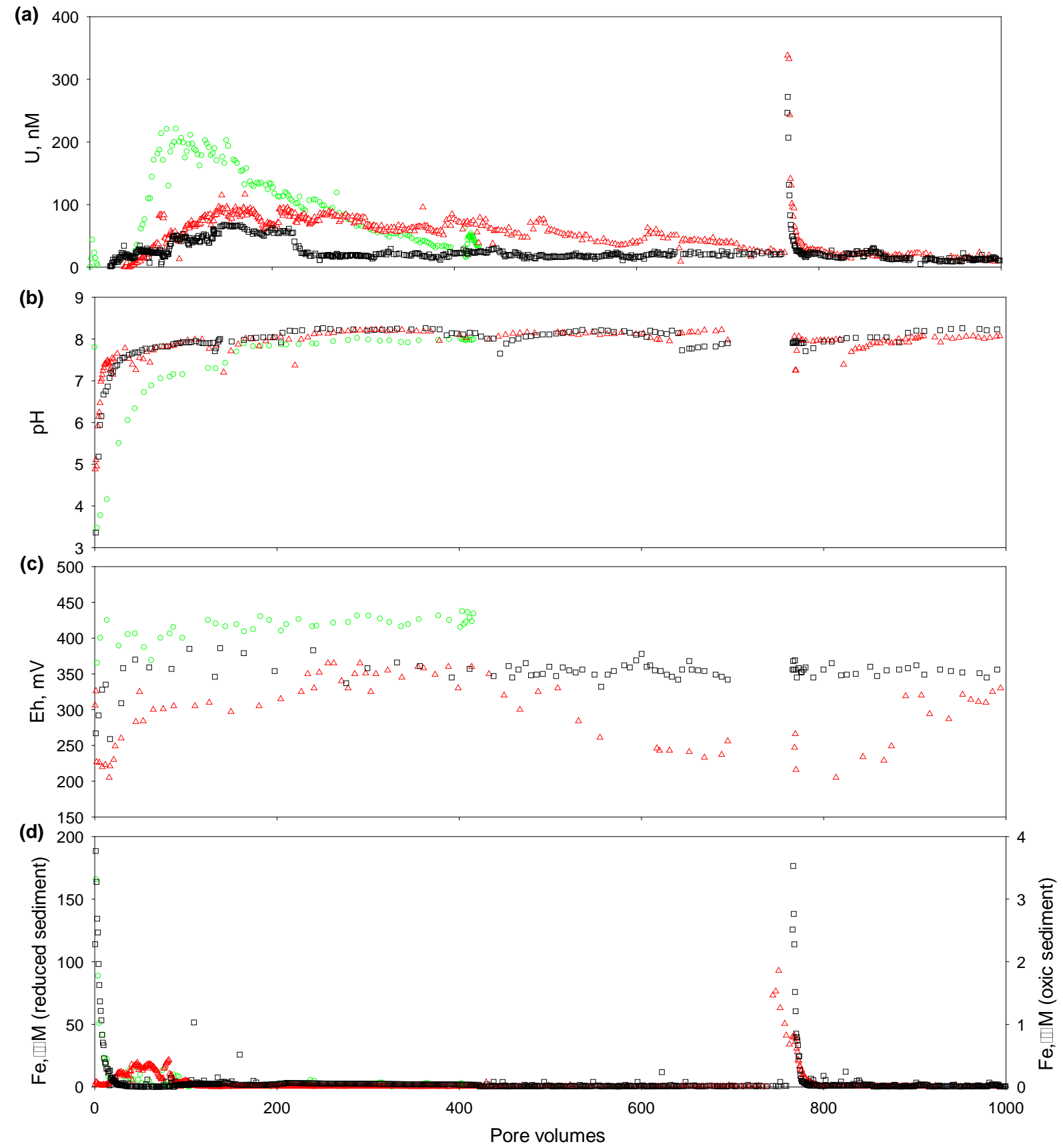

364 Figure 1. Concentration of (a) uranium and (d) iron mobilised from sediments with

365 corresponding changes in (b) $\mathrm{pH}$ and (c) Eh in the eluate during saturated flow through

366 column experiments. Columns were packed with; (०) oxic sediments that had been aged for 6

367 months; $(\Delta)$ nitrate-reducing sediments and ( $\square$ ) iron-reducing sediments. Seawater was used 
368 as the mobile phase. All values were above the limit of detection for the respective techniques

369 throughout the run. Figure 1(d) shows Fe mobilised from columns packed with reduced

370 sediments (nitrate-reducing and iron-reducing) on the primary axis and Fe mobilised from

371 columns packed with oxic sediments (aged 6 months) on the secondary axis.

372 

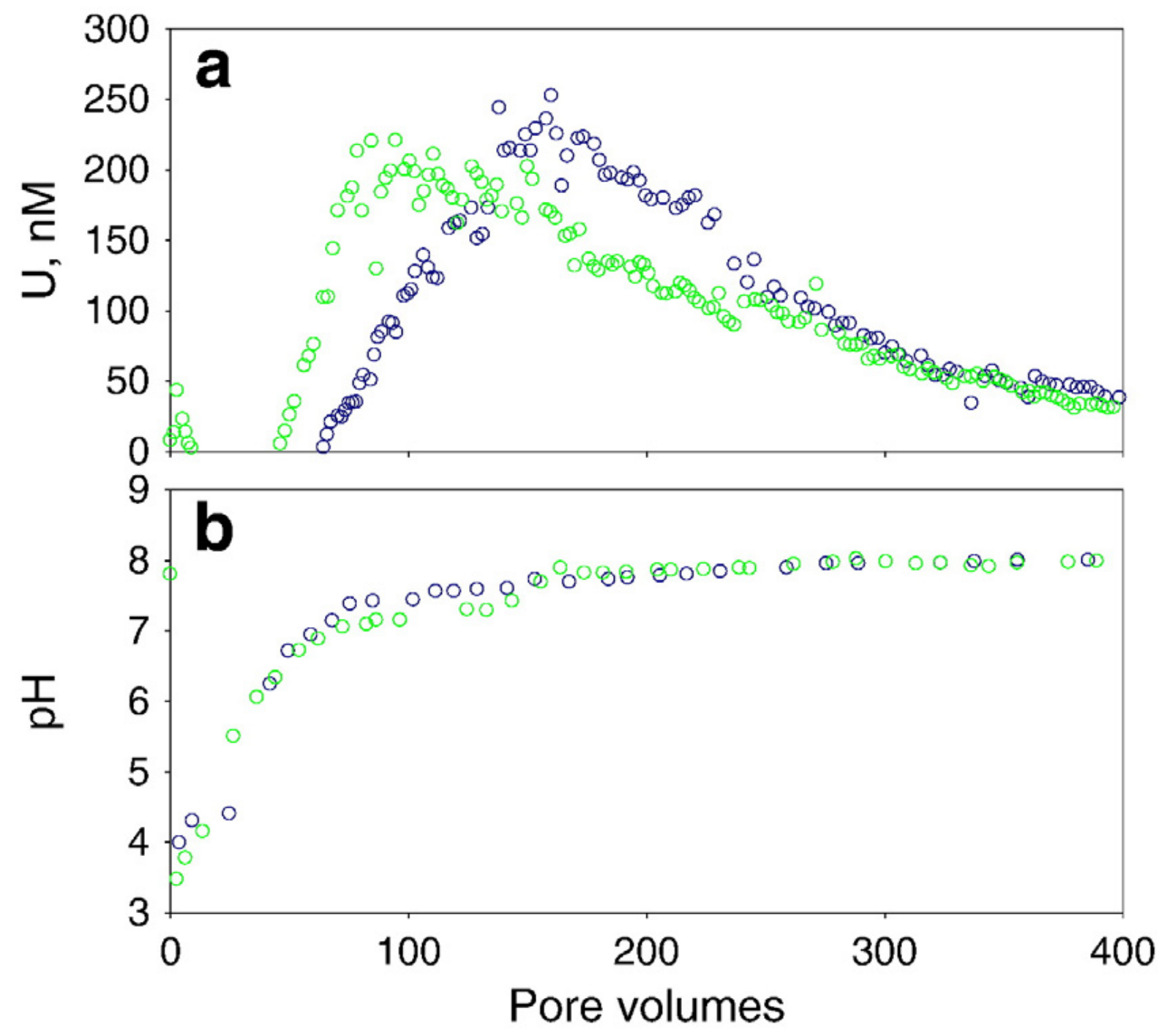

374 Fig. 2. Concentration of (a) uranium from sediments with corresponding changes in (b) $\mathrm{pH}$ in 375 the eluate during saturated flow through column experiments. Columns were packed with ( ) 376 oxic sediments (this study) and ( ) oxic Dounreay sediments that had been aged for 6 months;

377 using seawater as the mobile phase. All values were above the limit of detection throughout 378 the run for the respective techniques used. (For interpretation of the references to colour in 379 this figure legend, the reader is referred to the web version of this article.) 
381 Table 1. Conditions in the sediments and porewaters prior to use inmobilisation experiments.

382 Data show means \pm 1 standard deviation $(\mathrm{n}=10)$. LOD is the limit of detection - shown in 383 brackets.

384

Oxic (aged)

Nitrate reducing

Extensively iron reducing

385 Time

6 months

30 days

120 days

386 Eh, mV

$469 \pm 30$

$170 \pm 1$

$15 \pm 5$

$387 \quad \mathrm{pH}$

$3.9 \pm 0.3$

$6.4 \pm 0.6$

$7.0 \pm 0.5$

$388 \%$ U associated with sediments

389

$96 \pm 2$

$99 \pm 1$

$98 \pm 1$

$390 \quad \mathrm{NO}_{3}{ }^{-}, \mu \mathrm{M}$

$4800 \pm 300$

$4.4 \pm 0.6$

$<\mathrm{LOD}(2.5)$

391 Acid extractable Fe(II), $\mathrm{nmol} \mathrm{kg}^{-1}$

392

$<\operatorname{LOD}(0.55)$

$<$ LOD (0.55)

$16 \pm 1.0$

393

$\mathrm{SO}_{4}{ }^{2-}, \mu \mathrm{M}$

$3.8 \pm 0.7$

$4.2 \pm 0.9$

$4.8 \pm 0.1$ 
$398{ }^{1}$ Biogeochemistry and Environmental Analytical Chemistry Group, Biogeochemistry

399 Research Centre, Plymouth University, Plymouth, PL4 8AA, UK

$400{ }^{2}$ Consolidated Radio-isotope Facility, Plymouth University, Plymouth PL4 8AA, UK

$401{ }^{3}$ Kemakta Konsult, Box12655, 11293 Stockholm, Sweden.

402 *Corresponding author: E-mail: jane.eagling@plymouth.ac.uk

403 Telephone $+44(0) 1752584568$

404 Pages: 5

405 Tables: 3

406 Figures: 2

407

408

409

410

411

412 
413 Table S1: Constituents of synthetic groundwater (Wilkins et al., 2007).

\begin{tabular}{lc}
\hline Salt & Concentration, \\
& $g \mathrm{~L}^{-1}$ \\
\hline $\mathrm{KCl}$ & 0.0066 \\
$\mathrm{MgSO}_{4} .7 \mathrm{H}_{2} \mathrm{O}$ & 0.0976 \\
$\mathrm{MgCl}_{2} \cdot 6 \mathrm{H}_{2} \mathrm{O}$ & 0.0810 \\
$\mathrm{CaCO}_{3}$ & 0.1672 \\
$\mathrm{Na}_{2} \mathrm{SiO}_{3}$ & 0.0829 \\
$\mathrm{NaNO}_{3}$ & 0.0275 \\
$\mathrm{NaCl}^{\mathrm{NaHCO}}$ & 0.0094 \\
& \\
& \\
&
\end{tabular}

414

415

416

417

418

419

420

421 
422 Table S2. Sediment characteristics

\begin{tabular}{lll}
\hline Composition & Crediton & Dounreay \\
\hline Sand (\%) & 61 & 52 \\
Silt(\%) & 36 & 43 \\
Clay (\%) & 3 & 5 \\
Specific surface area (m $\left.{ }^{2} \mathrm{~g}^{-1}\right)$ & 6.57 & 5.92 \\
Cation exchange capacity (CEC) & $(9.3 \pm 1 \mathrm{mEq} / 100 \mathrm{~g}$ & $12 \pm 1 \mathrm{mEq} / 100 \mathrm{~g}$ \\
total organic carbon (\% by mass) & 2.0 & 4.0 \\
pH & $3.9 \pm 0.3$ & $4.4 \pm 0.2$ \\
\hline
\end{tabular}

423

424

425

426

427

428

429

430

431 
432 Table S3. Major elemental composition of the sediments determined using inductively

433 coupled plasma mass spectrometry (ICP-MS) following aqua regia digestion. Means shown $434(n=3) \pm 1$ standard deviation.

\begin{tabular}{|c|c|c|}
\hline & Crediton, mmol kg ${ }^{-1}$ & Dounreay, mmol kg-1 \\
\hline Al & $670 \pm 20$ & $300 \pm 9$ \\
\hline $\mathrm{Ca}$ & $38 \pm 1$ & $33 \pm 3$ \\
\hline Fe & $420 \pm 6$ & $280 \pm 8$ \\
\hline Mg & $120 \pm 4$ & $140 \pm 4$ \\
\hline Mn & $16 \pm 0.1$ & $5.0 \pm 0.3$ \\
\hline Si & $25 \pm 2$ & $25 \pm 1$ \\
\hline Sr & $0.15 \pm 0.01$ & $0.10 \pm 0.01$ \\
\hline
\end{tabular}

435 


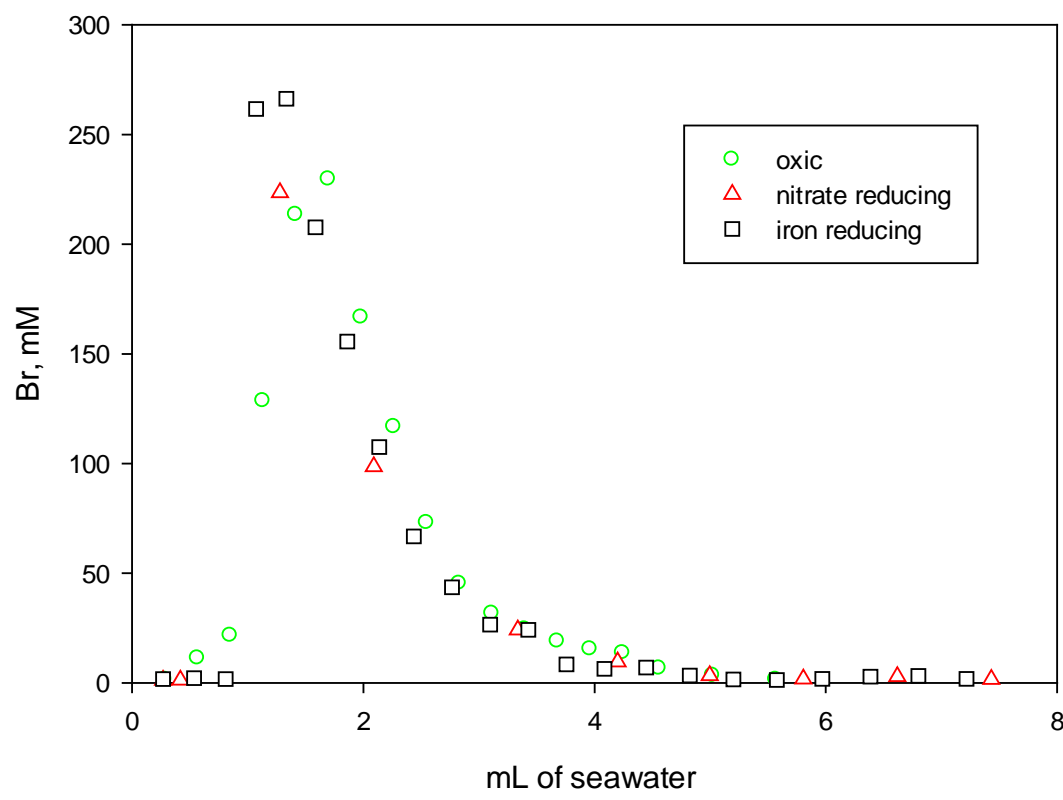

437

438 Figure SI 1. Characterisation of column experiments using a conservative $\mathrm{Br}^{-}$tracer. Columns

439 were packed with ( $($ ) oxic sediments that had been aged for 6 months; $(\Delta)$ nitrate-reducing

440 and ( $\square$ ) iron-reducing sediments, with seawater as the mobile phase.

441

442

443

444

445

446 


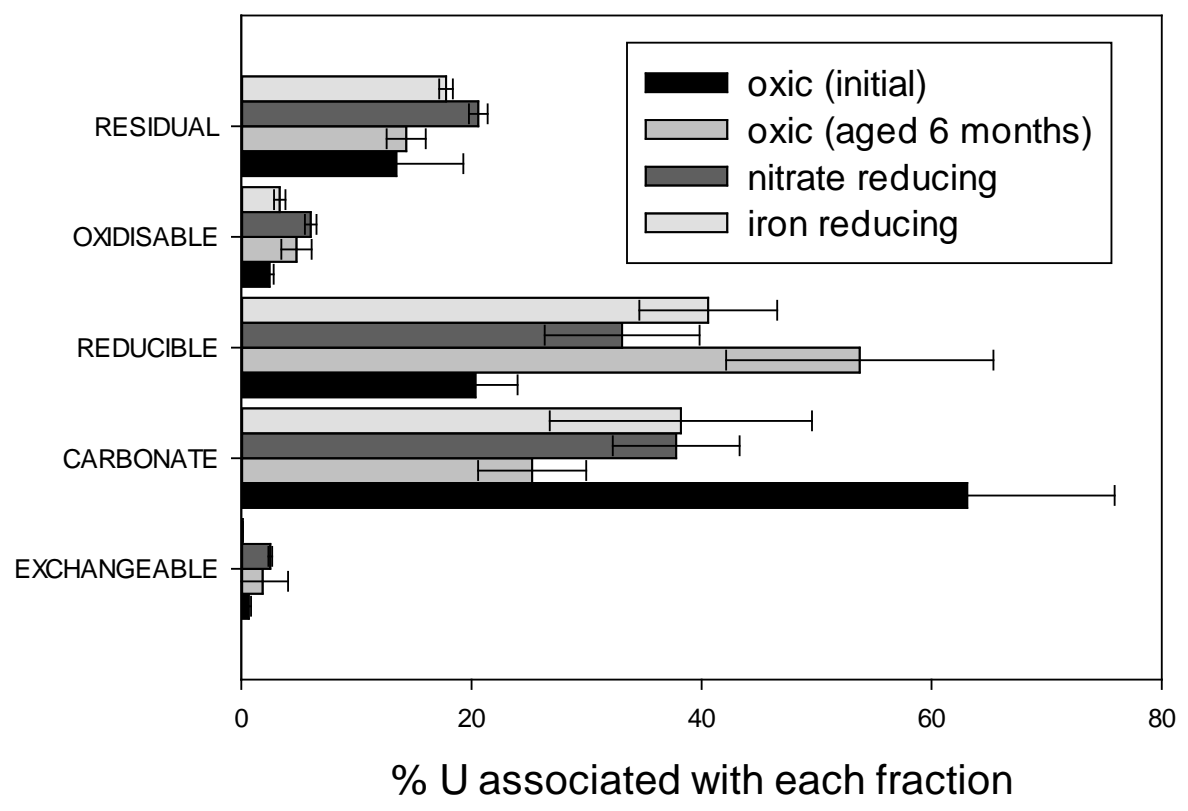

448 Figure SI 2. Sequential extraction data for U extracted from initially oxic sediment

449 (immediately after the sorption experiments), sediment aged for 6 months, nitrate-reducing 450 and iron-reducing sediments. Each bar represents the mean of three separate extractions \pm 1 451 standard deviation. Sequential extractions were carried out using a modified 5 step Tessier 452 sequential extraction procedure suitable for use in anaerobic environments (Keith-Roach et 453 al., 2003; Tessier et al., 1979). Oxic ( 6month aged) and reduced (nitrate-reducing and iron454 reducing) sediments were progressively leached to determine (1) the exchangeable fraction (1 $455 \mathrm{M} \mathrm{MgCl}_{2} / \mathrm{pH} 7 / 1 \mathrm{~h}$ ), (2) carbonate fraction (1 M sodium acetate/ $\mathrm{pH}$ 5/ $5 \mathrm{~h}$ ), (3) reducible 456 fraction (0.1 M ammonium oxalate/ $\mathrm{pH} 2 / 16 \mathrm{~h})$, (4) oxidisable fraction $\left(\mathrm{H}_{2} \mathrm{O}_{2}\right.$ / followed by 1 $457 \mathrm{M}$ ammonium acetate/ $6 \% \mathrm{HNO}_{3} / 16 \mathrm{~h}$ ) and (5) the residual fraction (aqua regia/ $2 \mathrm{~h}$ ). In 458 order to maintain anaerobic conditions, approximately 1.00 g of reduced sediment was 459 accurately weighed into each centrifuge tube within the anaerobic chamber. To prevent 460 oxidation of samples, all manipulations during steps 1-3 (i.e. those prior to the oxidising 461 leach) were also carried out in the anaerobic chamber. Leachate solutions for these steps were 
during shaking and centrifugation to prevent entry of air.

464

465

466

467

468

469

470

471

472

473

474

475

476

477

478

479

480

481

482

483

484

485

486

487

488

489

490

491

492

493

494

495

496

497

498

499

500

501

502

503

504

505

506

507

508

509

510

\section{References}

Abdelouas, A., Lutze, W., Nuttall, H.E., 1999. Oxidative dissolution of uraninite precipitated on Navajo sandstone. Journal of Contaminant Hydrology, 36(3-4): 353-375.

Barnes, C.E., Cochran, J.K., 1993. Uranium geochemistry in estuarine sediments: Controls on removal and release processes. Geochimica Et Cosmochimica Acta, 57(3): 555569.

Begg, J.D.C. et al., 2011. Bioreduction behavior of U(VI) sorbed to sediments. Geomicrobiology Journal, 28(2): 160-171.

Belles, M., Linares, V., Perello, G., Domingo, J.L., 2013. Human Dietary Exposure to Uranium in Catalonia, Spain. Biological Trace Element Research, 152(1): 1-8.

Campbell, K.M. et al., 2011. Oxidative Dissolution of Biogenic Uraninite in Groundwater at Old Rifle, CO. Environmental Science \& Technology, 45(20): 8748-8754.

Choy, C.C., Korfiatis, G.P., Meng, X., 2006. Removal of depleted uranium from contaminated soils. Journal of Hazardous Materials, 136(1): 53-60.

Dong, W.M. et al., 2005. Influence of calcite and dissolved calcium on uranium(VI) sorption to a Hanford subsurface sediment. Environmental Science \& Technology, 39(20): 7949-7955.

Duff, M.C., Coughlin, J.U., Hunter, D.B., 2002. Uranium co-precipitation with iron oxide minerals. Geochimica et Cosmochimica Acta, 66(20): 3533-3547.

Duquene, L. et al., 2008. Effect of biodegradable amendments on uranium solubility in contaminated soils. Science of the Total Environment, 391(1): 26-33.

Eagling, J., Worsfold, P.J., Blake, W.H., Keith-Roach, M.J., 2012. Mobilization of technetium from reduced sediments under seawater inundation and intrusion scenarios. Environmental Science \&Technology, 46 (21): 11798-803.

Eagling, J., Worsfold, P.J., Blake, W.H., Keith-Roach, M.J., 2013. Fate of ${ }^{90} \mathrm{Sr}$ and U(VI) in Dounreay sediments following saline inundation and erosion Chemosphere, http://dx.doi.org/10.1016/j.chemosphere.2013.02.059.

Finneran, K.T., Housewright, M.E., Lovley, D.R., 2002. Multiple influences of nitrate on uranium solubility during bioremediation of uranium-contaminated subsurface sediments. Environmental Microbiology, 4(9): 510-516.

Fox, P.M., Davis, J.A., Zachara, J.M., 2006. The effect of calcium on aqueous uranium(VI) speciation and adsorption to ferrihydrite and quartz. Geochimica et Cosmochimica Acta, 70(6): 1379-1387.

Ginder-Vogel, M., Criddle, C.S., Fendorf, S., 2006. Thermodynamic constraints on the oxidation of biogenic UO2 by Fe(III) (hydr) oxides. Environmental Science \& Technology, 40(11): 3544-3550.

Gómez, P. et al., 2006. Modeling of geochemical processes related to uranium mobilization in the groundwater of a uranium mine. Science of the Total Environment, 366(1): 295-309.

Gu, B.H. et al., 2005. Bioreduction of uranium in a contaminated soil column. Environmental Science \& Technology, 39(13): 4841-4847.

Guillaumont, R. et al., 2003. Update on the chemical thermodynamics of uranium, neptunium, plutonium, americium and technetium. . Elsevier, Amsterdam, The Netherlands.

Handley-Sidhu, S. et al., 2009. Corrosion and transport of depleted uranium in sand-rich environments. Chemosphere, 77(10): 1434-1439.

Keith-Roach, M.J., Morris, K., Dahlgaard, H., 2003. An investigation into technetium binding in sediments. Marine Chemistry, 81(3-4): 149-162. 
Komlos, J., Mishra, B., Lanzirotti, A., Myneni, S.C.B., Jaffe, P.R., 2008a. Real-time speciation of uranium during active bioremediation and $U(\mathrm{IV})$ reoxidation. Journal of Environmental Engineering-Asce, 134(2): 78-86.

Komlos, J., Peacock, A., Kukkadapu, R.K., Jaffe, P.R., 2008b. Long-term dynamics of uranium reduction/reoxidation under low sulfate conditions. Geochimica et Cosmochimica Acta, 72(15): 3603-3615.

Langmuir, D., 1978. Uranium solution-mineral equilibria at low temperatures with applications to sedimentary ore deposits. Geochimica et Cosmochimica Acta, 42(6): 547-569.

Law, G.T.W. et al., 2010. Role of nitrate in conditioning aquifer sediments for technetium bioreduction. Environmental Science \& Technology, 44(1): 150-155.

Law, G.T.W. et al., 2011. Uranium redox cycling in sediment and biomineral systems. Geomicrobiology Journal, 28(5-6): 497-506.

Liu, C.X., Zachara, J.M., Qafoku, N.P., Wang, Z.M., 2008. Scale-dependent desorption of uranium from contaminated subsurface sediments. Water Resources Research, 44(8): W08413.

Lovely, D., R, Phillips, E., J,P., 1986. Availability of ferric iron for microbial reduction in bottom sediments in freshwater tidal Potomac River. Applied and Environmental Microbiology, 52: 751-757.

Mackay, D.M., Roberts, P.V., Cherry, J.A., 1985. Transport of organic contaminants in groundwater. Environmental Science \& Technology, 19(5): 384-392.

Martinez, A., Garcia, L.M., Ivanovich, M., 1995. U and Th speciation in river sediments. Science of the Total Environment, 173(1-6): 203-209.

McKenzie, H., Armstrong-Pope, N., 2010. Groundwater Annual Report 2010. TECH000613, Sellafield Ltd.

McKinley, J.P. et al., 2006. Microscale controls on the fate of contaminant uranium in the vadose zone, Hanford Site, Washington. Geochimica Et Cosmochimica Acta, 70(8): 1873-1887.

Moon, H.S., Komlos, J., Jaffe, P.R., 2007. Uranium reoxidation in previously bioreduced sediment by dissolved oxygen and nitrate. Environmental Science \& Technology, 41(13): 4587-4592.

Moon, H.S., Komlos, J., Jaffe, P.R., 2009. Biogenic U(IV) oxidation by dissolved oxygen and nitrate in sediment after prolonged $\mathrm{U}(\mathrm{VI}) / \mathrm{Fe}(\mathrm{III}) / \mathrm{SO} 42$ - reduction. Journal of Contaminant Hydrology, 105(1-2): 18-27.

Morford, J.L. et al., 2007. Insights on geochemical cycling of U, Re and Mo from seasonal sampling in Boston Harbor, Massachusetts, USA. Geochimica Et Cosmochimica Acta, 71(4): 895-917.

Puigdomenech, I., 2004. Hydrochemical Equlibrium Constants Database (MEDUSA). Royal Institute of Technology, Stockolm.

Qafoku, N.P. et al., 2005. Kinetic desorption and sorption of $\mathrm{U}(\mathrm{VI})$ during reactive transport in a contaminated Hanford sediment. Environmental Science \& Technology, 39(9): 3157-3165.

Reeder, R.J., Nugent, M., Lamble, G.M., Tait, C.D., Morris, D.E., 2000. Uranyl incorporation into calcite and aragonite: XAFS and luminescence studies. Environmental Science \& Technology, 34(4): 638-644.

Reistad, O. et al., 2008. On-site radioactive soil contamination at the Andreeva Bay shore technical base, Northwest Russia. Journal of Environmental Radioactivity, 99(7): 1045-1055.

Riley, R.G., Zachara, J.M., 1992. Chemical contaminants on DOE lands and selection of contaminant mixtures for subsurface science research. DOE/ER--0547T; Other: ON: DE92014826.

Rodriguez, P.B., Tome, F.V., Lozano, J.C., Perez-Fernandez, M.A., 2008. Influence of soil texture on the distribution and availability of U-238, Th-230, and Ra-226 in soils. Journal of Environmental Radioactivity, 99(8): 1247-1254. 
Senko, J.M., Istok, J.D., Suflita, J.M., Krumholz, L.R., 2002. In-situ evidence for uranium immobilization and remobilization. Environmental Science \& Technology, 36(7): 1491-1496.

Sharp, J.O. et al., 2011. Uranium speciation and stability after reductive immobilization in aquifer sediments. Geochimica Et Cosmochimica Acta, 75(21): 6497-6510.

Sherman, D.M., Peacock, C.L., Hubbard, C.G., 2008. Surface complexation of U(VI) on goethite (alpha-FeOOH). Geochimica et Cosmochimica Acta, 72(2): 298-310.

Stookey, L.L., 1970. Ferrozine-a new spectrophotometric reagent for iron. Analytical Chemistry, 42(7): 779-781.

Sylwester, E.R., Hudson, E.A., Allen, P.G., 2000. The structure of uranium(VI) sorption complexes on silica, alumina, and montmorillonite. Geochimica et Cosmochimica Acta, 64(14): 2431-2438.

Tessier, A., Campbell, P.G.C., Bisson, M., 1979. Sequential extraction proceedure for the speciation of particulate trace- metals. Analytical Chemistry, 51(7): 844-851.

Ulrich, K.U. et al., 2008. Dissolution of biogenic and synthetic UO(2) under varied reducing conditions. Environmental Science \& Technology, 42(15): 5600-5606.

Wan, J.M. et al., 2008. Effects of organic carbon supply rates on uranium mobility in a previously bioreduced contaminated sediment. Environmental Science \& Technology, 42(20): 7573-7579.

Wazne, M., Korfiatis, G.P., Meng, X.G., 2003. Carbonate effects on hexavalent uranium adsorption by iron oxyhydroxide. Environmental Science \& Technology, 37(16): 3619-3624.

Whicker, J.J. et al., 2007. Uranium partition coefficients (K-d) in forest surface soil reveal long equilibrium times and vary by site and soil size fraction. Health Physics, 93(1): 36-46.

Wilkins, M.J., Livens, F.R., Vaughan, D.J., Beadle, I., Lloyd, J.R., 2007. The influence of microbial redox cycling on radionuclide mobility in the subsurface at a low-level radioactive waste storage site. Geobiology, 5(3): 293-301.

Wong, V.N.L. et al., 2010. Seawater causes rapid trace metal mobilisation in coastal lowland acid sulfate soils: Implications of sea level rise for water quality. Geoderma, 160(2): 252-263.

Yin, J. et al., 2011. Transient groundwater chemistry near a river: Effects on $\mathrm{U}(\mathrm{VI})$ transport in laboratory column experiments. Water Resources Research, 47: W04502.

Zachara, J.M. et al., 2013. Persistence of uranium groundwater plumes: Contrasting mechanisms at two DOE sites in the groundwater-river interaction zone. Journal of Contaminant Hydrology, 147: 45-72.

Zhong, L.R. et al., 2005. Oxidative remobilization of biogenic uranium(IV) precipitates: Effects of iron(II) and pH. Journal of Environmental Quality, 34(5): 1763-1771.

Zhou, P., Gu, B., 2005. Extraction of oxidised and reduced forms of uranium from contaminated soils: Effects of carbonate concentration and $\mathrm{pH}$. Environmental Science \& Technology, 39: 4435-4440. 